\title{
Pembuatan Sistem Informasi Manajemen Klinik dengan Rekam Medis: Studi Kasus di Klinik Kebon Arum Boyolali
}

\author{
Yanuar Wisnu Triaji, Rinta Kridalukmana, Eko Didik Widianto*) \\ Program Studi Sistem Komputer, Fakultas Teknik, Universitas Diponegoro \\ Jl. Prof. Soedarto, SH, Kampus Undip Tembalang, Semarang, Indonesia 50275
}

\begin{abstract}
The manual process of registration, inspection, payment, reporting and administrative employees at a clinic is not efficient. An information system to assist and facilitate a user in the process of a medical record is needed. The purpose of this research is to design and build an management information system for a clinic, specifically for Kebon Arum Clinic at Boyolali. The method used in this system development is the waterfall, which consists of the plan requirements, process design, and implementation. This application is built using PHP language, CodeIgniter framework, and MySQL database. As the results, the application can solve problems on manual clinic registration, queues, services, payments and patient data.
\end{abstract}

Keywords: Information Management System; Medical record; PHP; MySQL; Codeigniter

Abstrak - Proses pendaftaran, pemeriksaan, pembayaran, pelaporan dan karyawan administrasi di klinik sangat tidak efisien, dibutuhkan suatu sistem untuk membantu dan mempermudah pengguna dalam proses rekam medis. Tujuan dari penelitian ini adalah mengembangkan sistem informasi manajemen untuk klinik, yaitu klinik Kebon Arum di Boyolali. Metode pengembangan sistem yang digunakan dalam penelitian ini adalah metode Waterfall yang terdiri dari rencana kebutuhan, proses desain, dan implementasi. Aplikasi ini dibangun dengan bahasa pemrograman PHP, codeigniter framework, serta basis data MySQL. Hasil dari penelitian ini adalah sebuah aplikasi sistem informasi manajemen klinik dan sistem ini dapat mengatasi masalah pada pendaftaran klinik, antrian, layanan, pembayaran dan data pasien.

Kata Kunci - Sistem Informasi Manajemen; Rekam Medis; MySQl; PHP; Codeigniter

\section{Pendahuluan}

Rekam medis menjadi hal yang sangat penting dalam sistem manajemen klinik ataupun rumah sakit Selain untuk mencatat kunjungan pasien, rekam medis juga dapat digunakan untuk melakukan pelacakan terhadap riwayat penyakit seorang pasien. Rekam medis adalah fakta yang diberikan dengan keadaan pasien, riwayat penyakit dan pengobatan masa lalu serta saat ini yang ditulis oleh profesi kesehatan memberikan pelayanan kepada pasien tersebut[1]. Sistem adalah setiap satuan, secara konseptual atau fisik yang terdiri dari bagian-bagian dalam keadaan saling tergantung satu sama lain[2]. Informasi memliki banyak definisi, salah satunya pengertian informasi merupakan data yang telah diolah menjadi bentuk yang berarti bagi yang menerimanya dan bermanfaat dalam pengambilan keputusan mendatang[3]. Salah satu solusinya adalah dengan sistem informasi manajemen. Sistem Informasi Manajemen dapat menentukan berjalannya suatu perusahaan ataupun suatu organisasi yang mana menunjang informasi yang ada di dalamnya untuk pengambilan keputusan[4].

Yuliartanto dalam penelitiannya berpendapat bahwa setiap tindakan dalam upaya pengobatan dicatat dalam rekam medis pasien untuk menunjang pelayanan kesehatan. Data sebuah rekam medis berisi anamesis, hasil pemeriksaan, dan obat yang diberikan[5]. Wulandari dalam penelitiannya berpendapat bahwa pemanfaatan komputer sebagai sarana pembuatan dan pengiriman informasi medis merupakan upaya yang dapat mempercepat dan mempertajam bergeraknya informasi medis untuk kepentingan ketetapan tindakan medis[6].

Imbar dan Kurniawan dalam penelitiannya berpendapat bahwa banyaknya data pasien yang harus diolah dan data yang berkelanjutan dari riwayat penyakit pasien, membuat pengarsipan data riwayat pasien dengan metode manual (Hardcopy) sangat tidak efektif[7].

Penelitian ini memanfaatkan kemampuan komputer untuk menjalankan fungsi manajerial klinik kesehatan sehingga rekam medis tercatat dengan baik dan mampu mengurangi kesalahan pencatatan yang sering terjadi apabila dilakukan pencatatan secara manual. Sistem yang dibangun dalam penelitian ini berupa sistem berbasis web dengan bahasa pemrograman PHP yang merupakan bahasa berbentuk skrip yang ditempatkan dalam server [8]. Basisdata yang digunakan adalah MySQ1. MySQL adalah salah satu jenis basisdata server yang sangat terkenal dan banyak digunakan untuk membangun aplikasi web yang menggunakan basisdata sebagai sumber dan pengolahan datanya[9].

\footnotetext{
*) Penulis Korespondensi (E.D.Widianto)

Email: didik@live.undip.ac.id
} 


\section{Metode Penelitian}

Metode (waterfall) salah satunya model air terjun yang digunakan yaitu yang disebut model sekuensial linier atau alur hidup perangkat lunak secara sekuensial atau terurut dimulai dari analisis, desain, pengkodean, pengujian, dan pemeliharaan[10]. Terdapat 5 tahapan yaitu analisis kebutuhan, desain sistem, tahap programming, implementasi dan evaluasi.

Tahap pertama adalah tahap analisis kebutuhan sistem. Kebutuhan dibagi menjadi 2 yaitu kebutuhan fungsional dan kebutuhan non-fungsional. Kebutuhan fungsional meliputi pembagian level pengguna dan klasifikasi kemampuan sistem misalnya pencatatan rekam medis pasien dan pembuatan sistem kasir. Kebutuhan non-fungsional meliputi perangkat yang mendukung aplikasi.

Tahap kedua adalah desain sistem. Desain sistem meliputi desain antarmuka dan desain alur kerja program. Yang menjadi fokus pada tahap ini adalah pembuatan desain antarmuka yang interaktif dan perilaku sistem yang berjalan dengan akurat saat digunakan sehingga dapat mengurangi kesalahan-kesalahan yang dapat mengganggu pengguna, misalnya salah perhitungan obat yang mengakibatkan kesalahan penetapan biaya.

Tahap ketiga dalam penelitian aini adalah tahap pemrograman. Tahap ini dilakukan menggunakan Sublime Text 3 untuk menerjemahkan desain alur kerja aplikasi ke dalam sebuah baris kode bahasa pemrograman PHP.

Tahap keempat pada pengembangan sistem ini adalah tahap implementasi. Tahap implementasi disini berada pada tingkat pengujian sesuai kebutuhan sistem yang ada pada klinik. Dari tahap ini dapat diketahui apakah hasil yang ditunjukkan alat sudah sesuai dengan rencana awal sehingga dalam tahap ini dapat sekaligus menjalankan tahapan evaluasi.

\section{iII. Perancangan Sistem}

Aplikasi ini dirancang pada pemrograman PHP. Pada pengujian aplikasi ini berjalan pada localhost dengan local server XAMPP.

\section{A. Algoritma Perancangan Aplikasi}

Perancangan sistem harus memperhatikan fungsi utama dari sistem yaitu untuk pencatatan informasi medis di klinik. Sehingga perancangan sistem harus memperhatikan ketepatan dan keakuratan data serta kemudahan dalam proses input sehingga tidak terjadi kesalahan data. Gambar 1 menunjukkan diagram use case untuk alur kerja aplikasi.

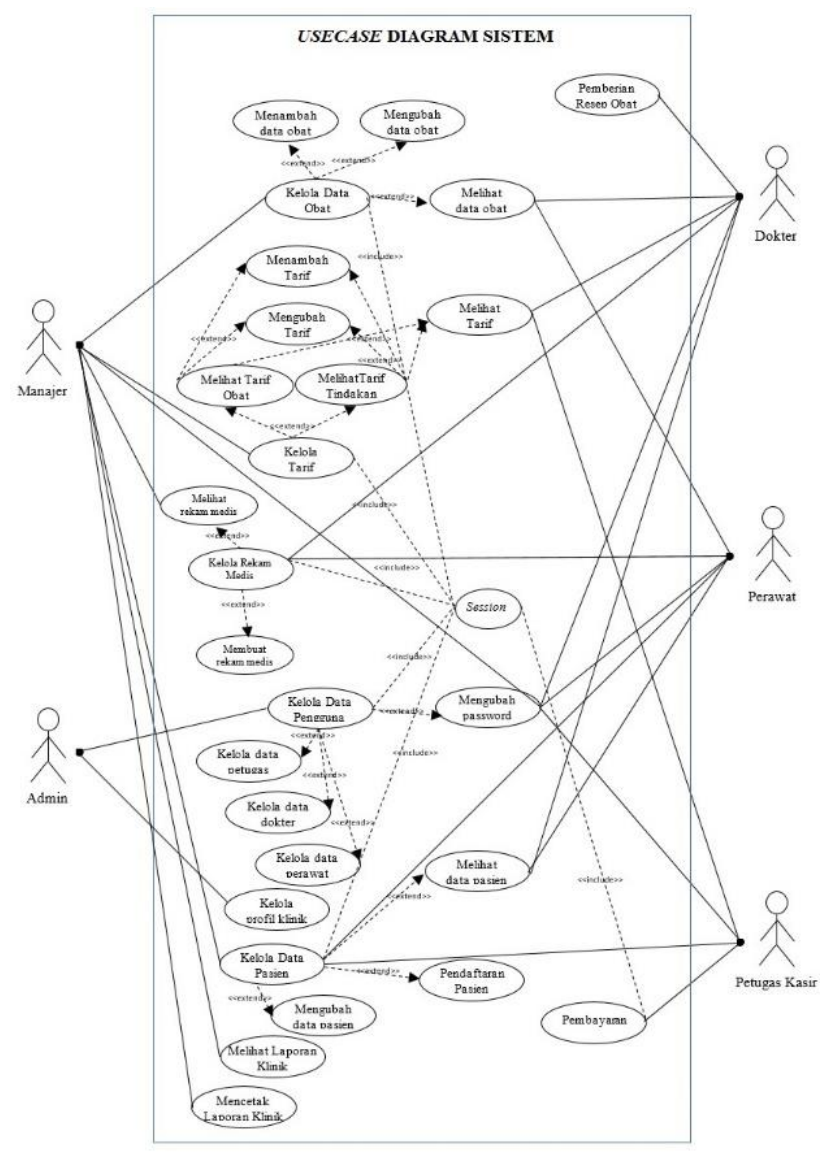

Gambar 1 Use-case Diagram Alur Kerja Program

Skenario use case berfungsi untuk memudahkan analisis pada fase berikutnya dengan melakukan pendeskripsian use case secara lebih rinci seperti aktor yang berperan, tujuan use case tersebut dan kondisi awal saat use case tersebut akan dilakukan.

1. Diagram aktifitas login

Pada Gambar 2 menunjukan aktifitas sistem informasi manajemen ketika login.

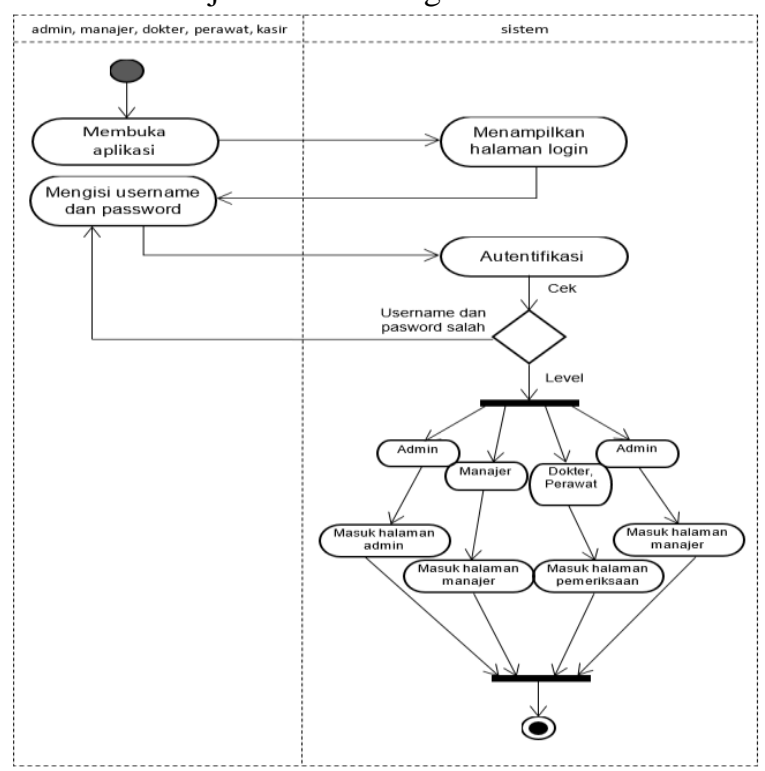

Gambar 2 Diagram aktifitas login 
2. Diagram aktifitas kelola data pasien

Gambar 3 menunjukkan diagram aktifitas kelola data pasien yang bisa dilakukan oleh petugas kasir.

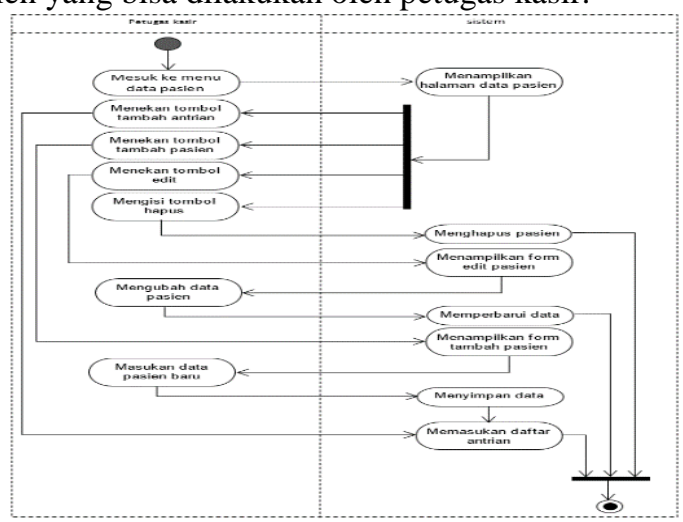

Gambar 3 Diagram aktifitas kelola data pasien

3. Diagram aktifitas kelola data pengguna

Gambar 4 menunjukkan diagram aktifitas terhadap pengelolaan data pengguna yang dilakukan oleh admin.

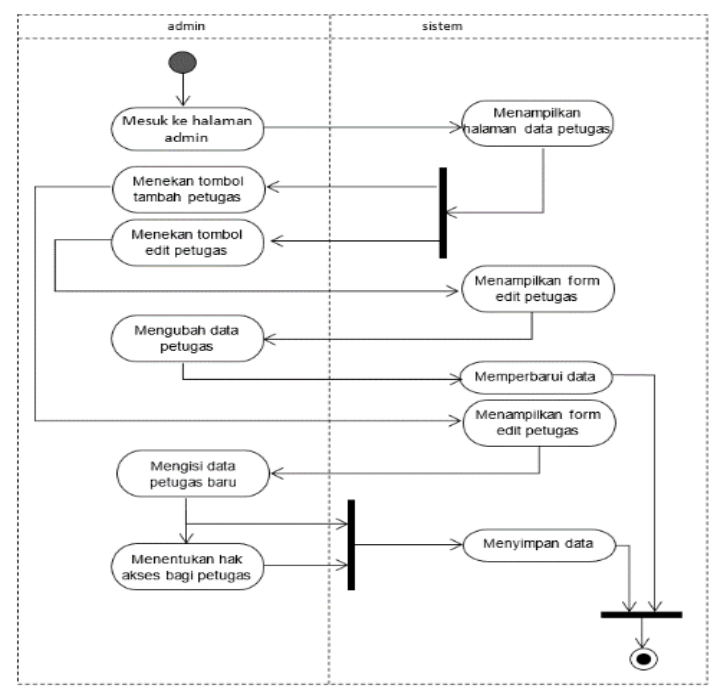

Gambar 4Diagram aktifitas kelola data petugas

4. Diagram aktifitas kelola rekam medis pasien Gambar 5 menunjukkan diagram aktifitas terhadap kelola data rekam medis yang dilakukan oleh dokter dan dibantu oleh perawat.

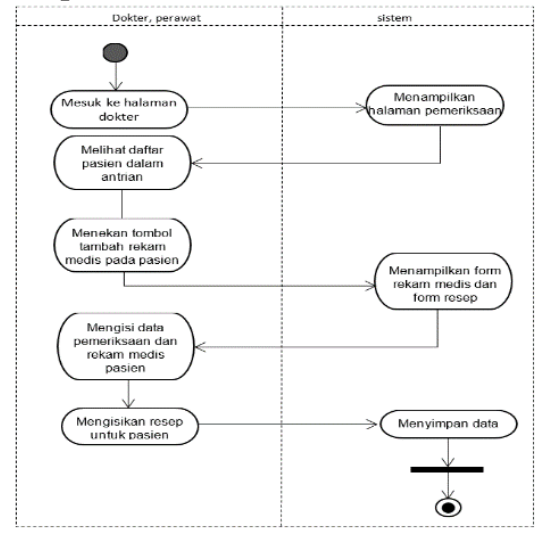

Gambar 5 Diagram aktifitas kelola rekam medis

5. Diagram aktifitas ubah password
Gambar 6 menunjukan diagram aktifitas untuk mengubah password yang dapat dilakukan oleh semua pengguna.

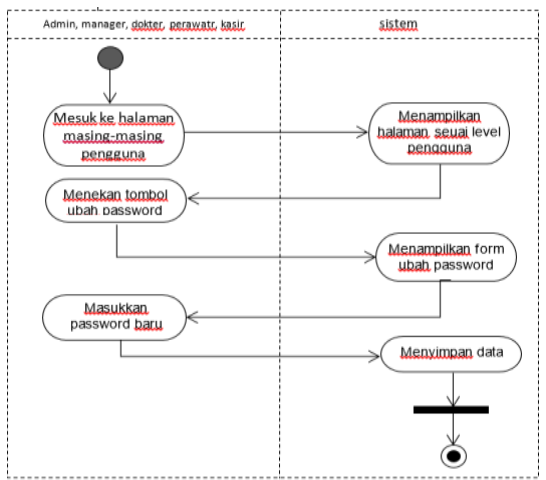

Gambar 6Diagram aktifitas ubah password

B. Desain Basisdata

Sistem informasi yang baik adalah sistem yang memiliki struktur basisdata yang normal. Oleh karena itu, perancangan basisdata juga merupakan bagian penting ketika membangun sebuah sistem informasi. Gambar 7 merupakan Entity Relationship Diagram (ERD).

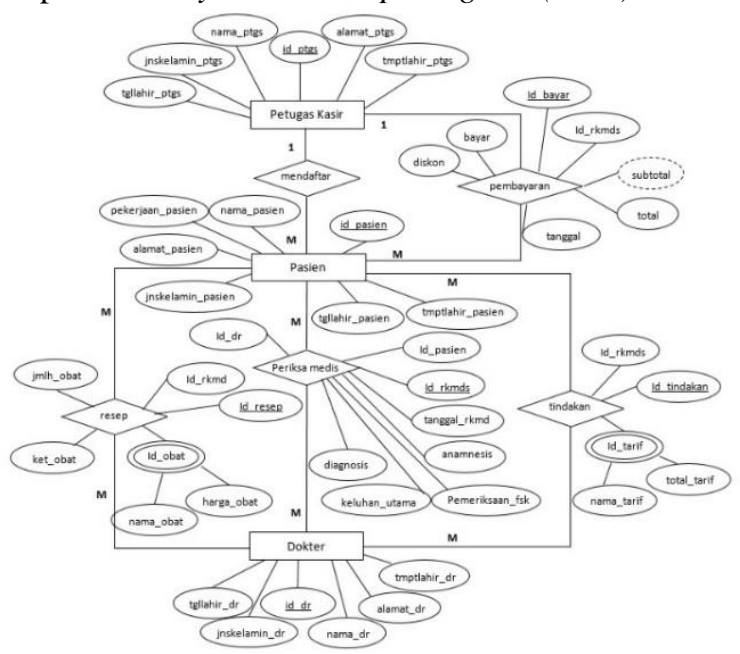

Gambar 7 Entity Realtionship Diagram

Desain entitas basisdata untuk sistem ini akan dijelaskan sebagai berikut.

\section{Tabel tb_user}

Tabel tb_user berguna menyimpan data pengguna sistem berdasarkan pekerjaan petugas dengan menyesuaikan hak akses agar bisa masuk ke halaman sistem masing-masing. Struktur tabel tb_user dapat dilihat pada Tabel 1.

Tabel 1 Daftar Tabel tb_user

\begin{tabular}{|c|c|c|c|c|}
\hline Field & Type & Size & Key & Keterangan \\
\hline id_user & int & 3 & primary & $\begin{array}{ll}\text { Berisi } & \text { id } \\
\text { pengguna }\end{array}$ \\
\hline username & Varchar & 25 & & $\begin{array}{l}\text { Berisi username } \\
\text { pengguna }\end{array}$ \\
\hline pasword & Varchar & 42 & & $\begin{array}{l}\text { Berisi password } \\
\text { pengguna }\end{array}$ \\
\hline level_user & Enum & & & $\begin{array}{l}\text { Berisi level atau } \\
\text { hak akses } \\
\text { pengguna }\end{array}$ \\
\hline nama_user & varchar & 100 & & $\begin{array}{l}\text { Berisi nama } \\
\text { petugas }\end{array}$ \\
\hline $\begin{array}{l}\text { tmptlahir_ } \\
\quad \text { user }\end{array}$ & varchar & 25 & & $\begin{array}{l}\text { Berisi tempat } \\
\text { lahir petugas }\end{array}$ \\
\hline
\end{tabular}




\begin{tabular}{|c|c|c|c|}
\hline $\begin{array}{l}\text { tgllahir_ } \\
\text { user }\end{array}$ & varchar & 15 & $\begin{array}{l}\text { Berisi tanggal } \\
\text { lahir petugas }\end{array}$ \\
\hline $\begin{array}{c}\text { alamat_ } \\
\text { user }\end{array}$ & varchar & 250 & $\begin{array}{l}\text { Berisi alamat } \\
\text { tinggal petugas }\end{array}$ \\
\hline $\begin{array}{c}\text { jnskelamin_ } \\
\text { user }\end{array}$ & varchar & 10 & $\begin{array}{l}\text { Berisi jenis } \\
\text { kelamin petugas }\end{array}$ \\
\hline $\begin{array}{l}\text { telepon_ } \\
\text { user }\end{array}$ & varchar & 12 & $\begin{array}{l}\text { Berisi nomor } \\
\text { telepon petugas }\end{array}$ \\
\hline poto & longtext & & $\begin{array}{l}\text { Berisi nama file } \\
\text { foto petugas }\end{array}$ \\
\hline
\end{tabular}

\section{Tabel tb_obat}

Tabel tb_obat digunakan untuk menyimpan data-data obat-obat yang mempunyai field yang ditunjukan pada Tabel 2.

Tabel 2 Daftar Tabel tb_obat

\begin{tabular}{|c|c|c|c|c|}
\hline Field & Type & Size & Key & Keterangan \\
\hline id_obat & int & 3 & primary & Berisi id obat \\
\hline nama_obat & varchar & 100 & & Berisi nama oba \\
\hline kandungan_obat & varchar & 250 & & $\begin{array}{l}\text { Berisi } \\
\text { kandungan obat }\end{array}$ \\
\hline golongan_obat & varchar & 100 & & $\begin{array}{l}\text { Berisi jenis atau } \\
\text { golongan obat }\end{array}$ \\
\hline tglbeli_obat & varchar & 20 & & $\begin{array}{l}\text { Berisi tangga } \\
\text { beli obat }\end{array}$ \\
\hline tglkl_obat & varchar & 20 & & $\begin{array}{l}\text { Berisi tangga } \\
\text { kadaluarsa obat }\end{array}$ \\
\hline harga_obat & int & 5 & & $\begin{array}{l}\text { Berisi harga bel } \\
\text { obat }\end{array}$ \\
\hline hargajual_obat & int & 10 & & $\begin{array}{l}\text { Berisi harga jua } \\
\text { obat }\end{array}$ \\
\hline stok_obat & int & 10 & & $\begin{array}{l}\text { Berisi jumlah } \\
\text { persedian obat }\end{array}$ \\
\hline
\end{tabular}

\section{Tabel tb_tarif}

Tabel tb_tarif digunakan untuk menyimpan data tarif tindakan oleh dokter pada klinik yang mempunyai field yang ditunjukkan pada Tabel 3 .

Tabel 3 Daftar Tabel tb_tarif

\begin{tabular}{|c|c|c|c|c|}
\hline Field & Type & Size & Key & Keterangan \\
\hline id_tarif & int & 5 & primary & Berisi id obat \\
\hline nama_tarif & varchar & 250 & & Berisi nama obat \\
\hline tarif_dokter & varchar & 10 & & $\begin{array}{l}\text { Berisi kandungan } \\
\text { obat }\end{array}$ \\
\hline tarif_asisten & varchar & 10 & & $\begin{array}{l}\text { Berisi jenis atau } \\
\text { golongan obat }\end{array}$ \\
\hline tarif_klinik & varchar & 10 & & $\begin{array}{l}\text { Berisi tanggal beli } \\
\text { obat }\end{array}$ \\
\hline tarif_bhp & varchar & 10 & & $\begin{array}{l}\text { Berisi tanggal } \\
\text { kadaluarsa obat }\end{array}$ \\
\hline total_tarif & int & 10 & & $\begin{array}{l}\text { Berisi harga beli } \\
\text { obat }\end{array}$ \\
\hline
\end{tabular}

\section{Tabel tb_pasien}

Tabel tb_pasien digunakan untuk menyimpan datadata pasien yang pernah berobat di klinik. Tabel 4 menunjukkan isi dari tb_pasien.

Tabel 4 Daftar Tabel tb_pasien

\begin{tabular}{|c|c|c|c|c|}
\hline Field & Type & Size & Key & Keterangan \\
\hline id_pasien & int & 5 & primary & Berisi id pasien \\
\hline nama_pasien & varchar & 100 & & $\begin{array}{l}\text { Berisi nama } \\
\text { pasien }\end{array}$ \\
\hline $\begin{array}{l}\text { tmptlahir_ } \\
\text { pasien }\end{array}$ & varchar & 25 & & $\begin{array}{l}\text { Berisi tempat } \\
\text { lahir pasien }\end{array}$ \\
\hline $\begin{array}{l}\text { tgllahir_ } \\
\text { pasien }\end{array}$ & varchar & 10 & & $\begin{array}{l}\text { Berisi tanggal } \\
\text { lahir pasien }\end{array}$ \\
\hline $\begin{array}{l}\text { alamat- } \\
\text { _pasien }\end{array}$ & varchar & 100 & & $\begin{array}{l}\text { Berisi alamat } \\
\text { tinggal pasien }\end{array}$ \\
\hline
\end{tabular}

\begin{tabular}{|c|c|c|c|}
\hline $\begin{array}{l}\text { jnskelamin } \\
\text { pasien }\end{array}$ & varchar & 10 & $\begin{array}{l}\text { Berisi jenis } \\
\text { kelamin pasien }\end{array}$ \\
\hline $\begin{array}{l}\text { telepon_- } \\
\text { pasien }\end{array}$ & varchar & 12 & $\begin{array}{l}\text { Berisi nomor } \\
\text { telepon pasien }\end{array}$ \\
\hline pekerjaan_dr & varchar & 25 & $\begin{array}{l}\text { Berisi pekerjaan } \\
\text { pasien }\end{array}$ \\
\hline usia_pasien & varchar & 10 & $\begin{array}{l}\text { Berisi usia pasien } \\
\text { sekarang }\end{array}$ \\
\hline
\end{tabular}

\section{Tabel tb_bayar}

Tabel tb_bayar digunakan untuk penyimpanan pembayaran yang dilakukan pasien mengacu untuk pemberian kwitansi/nota pembayaran kepada pasien. Berikut merupakan isi dari tabel tb_bayar ditunjukan pada Tabel 5.

\begin{tabular}{|c|c|c|c|c|}
\hline Field & Type & Size & Key & Keterangan \\
\hline id_bayar & int & 11 & primary & Berisi id bayar \\
\hline id_rkmd & varchar & 20 & foreign & $\begin{array}{l}\text { Berisi id rekam } \\
\text { medis }\end{array}$ \\
\hline subtotal & varchar & 10 & & $\begin{array}{l}\text { Berisi total tarif } \\
\text { pemeriksaan dan } \\
\text { obat pasien }\end{array}$ \\
\hline diskon & varchar & 10 & & $\begin{array}{l}\text { Berisi diskon yang } \\
\text { diberikan pihak } \\
\text { klinik }\end{array}$ \\
\hline total & varchar & 10 & & $\begin{array}{l}\text { Berisi total tarif } \\
\text { pemeriksaan dan } \\
\text { obat setelah } \\
\text { dikurangi diskon }\end{array}$ \\
\hline
\end{tabular}

\section{Tabel tb_rekammedis}

Tabel tb_rekammedis digunakan untuk menyimpan riwayat atau rekammedis dari pemeriksaan yang dilakukan dokter terhadap pasien. Tabel 6 menunjukkan isi dari tb_rekammedis.

Tabel 6 Daftar Tabel tb_rekammedis

\begin{tabular}{|c|c|c|c|c|}
\hline Field & $\begin{array}{c}\text { Typ } \\
\text { e }\end{array}$ & $\begin{array}{l}\mathrm{Si} \\
\mathbf{z e}\end{array}$ & Key & Keterangan \\
\hline id_rkmd & $\begin{array}{l}\text { varc } \\
\text { har }\end{array}$ & 15 & $\begin{array}{c}\text { primar } \\
\mathrm{y}\end{array}$ & $\begin{array}{l}\text { Berisi id rekam medis } \\
\text { atau riwayat } \\
\text { pemeriksaan pasien }\end{array}$ \\
\hline tanggal_rkmd & $\begin{array}{l}\text { varc } \\
\text { har }\end{array}$ & 10 & & $\begin{array}{l}\text { Berisi tanggal saat } \\
\text { pasien melakukan } \\
\text { pemeriksaan }\end{array}$ \\
\hline id_pasien & int & 5 & foreign & Berisi id pasien \\
\hline keluhan_utama & $\begin{array}{l}\text { long } \\
\text { text }\end{array}$ & & & $\begin{array}{l}\text { Berisi keluhan utama } \\
\text { pasien }\end{array}$ \\
\hline anamnesis & $\begin{array}{l}\text { long } \\
\text { text }\end{array}$ & & & $\begin{array}{l}\text { Berisi anamnesis } \\
\text { pasien }\end{array}$ \\
\hline pemeriksaan_fsk & $\begin{array}{r}\text { long } \\
\text { text }\end{array}$ & & & $\begin{array}{l}\text { Berisi pemeriksaan } \\
\text { fisik pasien }\end{array}$ \\
\hline hsl_penunjang & $\begin{array}{r}\text { long } \\
\text { text }\end{array}$ & & & $\begin{array}{l}\text { Berisi hasil penunjang } \\
\text { pasien }\end{array}$ \\
\hline diagnosis & $\begin{array}{r}\text { long } \\
\text { text }\end{array}$ & & & $\begin{array}{l}\text { Berisi diagnosa } \\
\text { terhadap pasien }\end{array}$ \\
\hline diagnosis_bdg & $\begin{array}{r}\text { long } \\
\text { text }\end{array}$ & & & $\begin{array}{ll}\text { Berisi } & \text { diagnosa } \\
\text { banding } & \text { terhadap } \\
\text { pasien } & \end{array}$ \\
\hline tindakan & $\begin{array}{r}\text { long } \\
\text { text }\end{array}$ & & & $\begin{array}{l}\text { Berisi tindakan yang } \\
\text { dilakukan dokter } \\
\text { terhadap pasien }\end{array}$ \\
\hline saran & $\begin{array}{r}\text { long } \\
\text { text }\end{array}$ & & & $\begin{array}{l}\text { Berisi saran untuk } \\
\text { pasien }\end{array}$ \\
\hline tensi_darah & $\begin{array}{l}\text { varc } \\
\text { har }\end{array}$ & 10 & & $\begin{array}{l}\text { Berisi tensi darah } \\
\text { pasien }\end{array}$ \\
\hline detak_jantung & $\begin{array}{l}\text { varc } \\
\text { har }\end{array}$ & 10 & & $\begin{array}{l}\text { Berisi detak jantung } \\
\text { pasien }\end{array}$ \\
\hline
\end{tabular}




\begin{tabular}{|c|c|c|c|}
\hline suhu_badan & $\begin{array}{l}\text { varc } \\
\text { har }\end{array}$ & 10 & $\begin{array}{lll}\begin{array}{l}\text { Berisi } \\
\text { pasien }\end{array} & & \\
\end{array}$ \\
\hline berat_badan & $\begin{array}{l}\text { varc } \\
\text { har }\end{array}$ & 10 & $\begin{array}{l}\text { Berisi berat badan } \\
\text { pasien }\end{array}$ \\
\hline bmi & $\begin{array}{l}\text { varc } \\
\text { har }\end{array}$ & 10 & Berisi bmi pasien \\
\hline dokter & $\begin{array}{l}\text { varc } \\
\text { har }\end{array}$ & $\begin{array}{c}10 \\
0\end{array}$ & $\begin{array}{l}\text { Berisi dokter yang } \\
\text { memeriksa pasien }\end{array}$ \\
\hline
\end{tabular}

\section{Tabel tb_tindakan}

Tabel tb_tindakan digunakan untuk menyimpan catatan tindakan pemeriksaan yang dilakukan dokter terhadap pasien. Tabel 7 menunjukkan isi dari tb_tindakan.

Tabel 7 Daftar Tabel tb_tindakan

\begin{tabular}{ccccll}
\hline Field & Type & Size & & Key & \multicolumn{1}{c}{ Keterangan } \\
$\begin{array}{c}\text { id_- } \\
\text { tindakan } \\
\text { id_tarif }\end{array}$ & int & 10 & primary & Berisi id bayar \\
id_rkmd & varchar & 15 & foreign & $\begin{array}{l}\text { Berisi primarykey } \\
\text { pada tabel tarif } \\
\text { ferisi } \\
\text { primarykey pada } \\
\text { tabel rekammedis }\end{array}$ \\
\hline
\end{tabular}

\section{Tabel tb_resep}

Tabel tb_resep digunakan untuk menyimpan catatan resep obat yang dilakukan dokter terhadap pasien. Tabel 8 menunjukkan isi dari tb_resep.

Tabel 8 Daftar Tabel tb_resep

\begin{tabular}{|c|c|c|c|c|}
\hline Field & Type & Size & Key & Keterangan \\
\hline id_resep & int & 10 & primary & Berisi id bayar \\
\hline id_obat & int & 5 & foreign & $\begin{array}{l}\text { Berisi primarykey } \\
\text { pada tabel obat }\end{array}$ \\
\hline jumlah_obat & int & 5 & & $\begin{array}{l}\text { Berisi jumlah obat } \\
\text { yang digunakan }\end{array}$ \\
\hline ket_obat & $\begin{array}{l}\text { long } \\
\text { text }\end{array}$ & & & $\begin{array}{l}\text { Berisi keterangan } \\
\text { obat yang } \\
\text { diberikan. }\end{array}$ \\
\hline id_rkmd & varchar & 15 & foreign & $\begin{array}{l}\text { Berisi data } \\
\text { primarykey pada } \\
\text { tabel rekammedis }\end{array}$ \\
\hline
\end{tabular}

\section{Perancangan Struktur Menu}

Struktur menu untuk admin dideskripsiskan pada Gambar 8. Admin mengatur pengguna sistem dan hak aksesnya dengan beberapa menu.

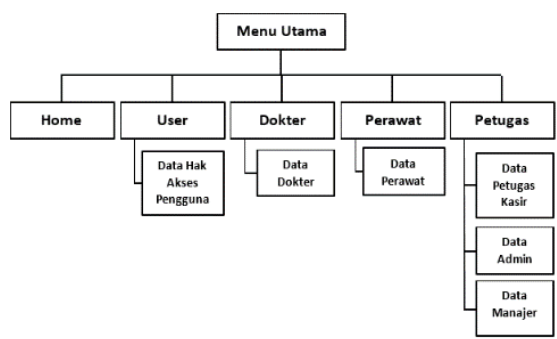

Gambar 8 Struktur Menu untuk Admin

Struktur menu untuk manajer diperlihatkan pada Gambar 9.

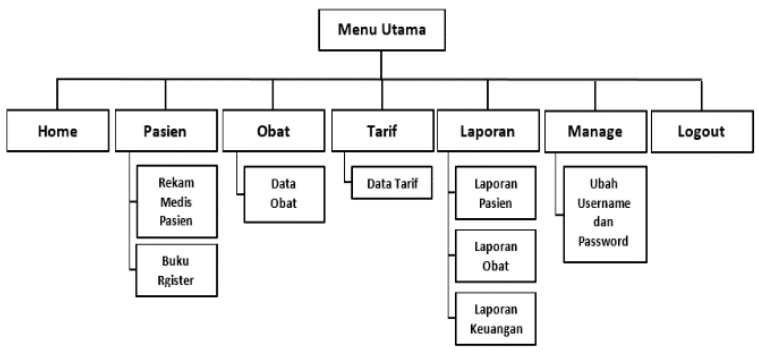

Gambar 9 Struktur Menu untuk Manajer

Struktur menu untuk dokter dan perawat memiliki fungsi yang sama, diperlihatkan pada Gambar 10 .

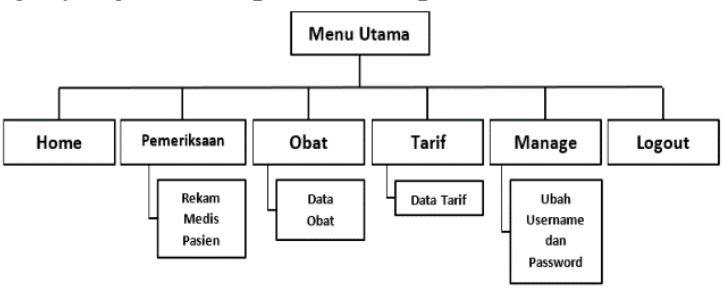

Gambar 10 Struktur Menu untuk Dokter dan Perawat

Struktur menu utama kasir meliputi bagian pendafataran pasien, diperlihatkan pada Gambar 11.

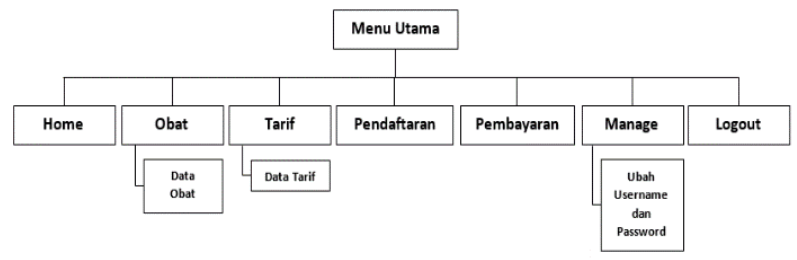

Gambar 11 Struktur Menu untuk Kasir

\section{IMPLEMETASI DAN PENGUJIAN SISTEM}

\section{Halaman Login}

Pada saat pengguna masuk ke sistem, pengguna dihadapkan dengan tampilan index sistem berupa halaman login. Pada halaman login, pengguna di minta memasukkan username dan password. Halaman ini berfungsi sebagai verifikasi pengguna yang masuk. Sistem login ini juga memiliki otomatisasi hak akses berdasarkan level pengguna yang login.

\section{Halaman Admin}

Halaman admin digunakan untuk menetukan hak akses pengguna. Selain menu utama admin, terdapat menu user. Pada menu user merupakan bagian utama dari proses sistem aplikasi, di mana menu user ini berguna untuk menambahkan data baru pengguna dan sekaligus mengatur hak akses atau pangkat pengguna terhadap sistem. Berikut ini merupakan tampilan dari menu user ditunjukan dengan Gambar 12. 


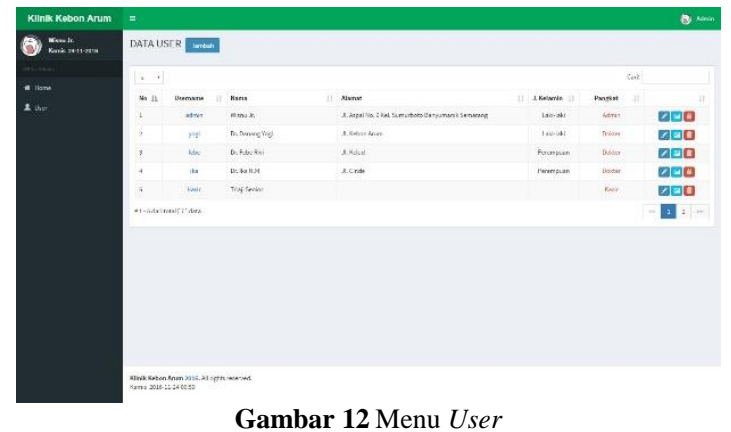

Gambar 12 Menu User

Pada menu user terdapat beberapa fungsional antara lain, tabel user berguna menampilkan data user berserta pangkat (hak akses).

\section{Halaman Kasir}

Halaman kasir merupakan bagian dimana proses sistem pada klinik. Setelah pemeriksaan pasien oleh dokter selesai, maka pasien akan masuk ke dalam data antrian bayar pada kasir. Petugas kasir akan melayani proses pembayaran tersebut. Berikut ini merupakan tampilan-tampilan menu pada halaman kasir.

a. Menu Halamn Utama

Halaman utama pada kasir ialah halaman di mana proses sistem berlangsung. Gambar 13 menunjukkan tampilan dari halaman utama kasir.

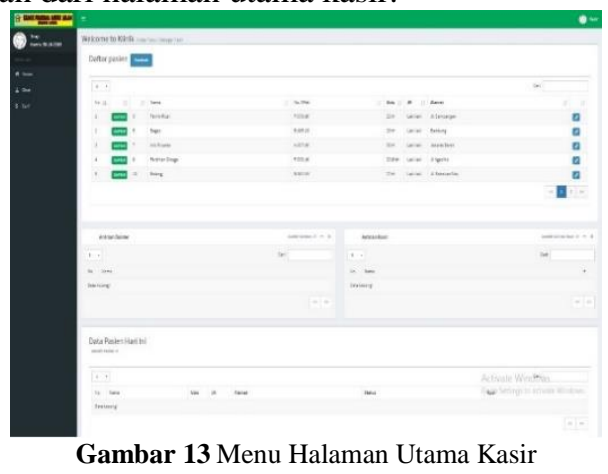

Untuk pasien yang telah terdaftar sebelumnya, petugas cukup mencari data pasien di tabel daftar pasien kemudian mendaftarkannya ke antrian dokter yang tersedia. Setelah proses pemeriksaan dokter selesai, pasien akan langsung masuk ke tabel antrian kasir.

Pada tabel antrian kasir akan muncul data pasien yang telah melewati proses sistem pemeriksaan oleh dokter. Gambar 14 menunjukkan tampilan proses pembayaran.

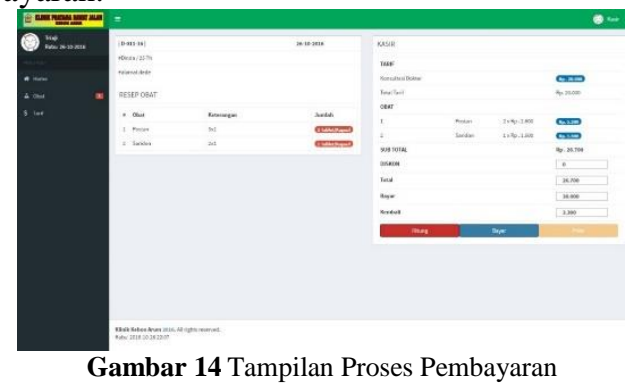

Pada tabel data pasien hari ini menunjukkan pasien yang periksa pada hari tersebut. Terdapat kolom status yang menjelaskan proses yang sedang dilakukan oleh pasien. Apabila status pasien menunjukan telah selesai, maka proses sistem terhadap pasien tersebut telah selesai. b. Menu Obat

Menu obat pada kasir digunakan untuk melihat daftar obat beserta harga obat yang tersedia pada klinik.

c. Menu Tarif

Menu tarif pada kasir menunjukkan daftar nama tindakkan beserta tarif tindakan yang dapat dilakukan pada klinik.

\section{Halaman Dokter}

Halaman dokter merupakan bagian dari proses sistem pada klinik. Hanya pengguna dengan level dokter yang dapat mengakses halaman ini.

a. Menu Halaman Utama Dokter

Pada menu halaman utama dokter terdapat beberapa bagian, antara lain tabel antrian pasien dan tabel pasien hari ini. Menu halaman utama dokter ditunjukkan pada Gambar 15 .

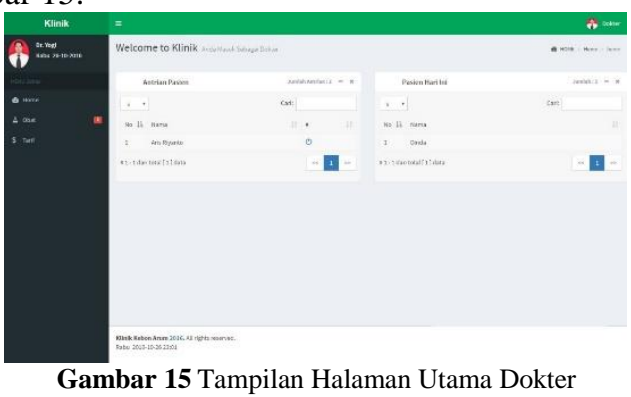

b. Halaman Pemeriksaan

Halaman pemeriksaan dokter berisi form input hasil pemeriksaan terhadap pasien. Halaman pemeriksaan ditunjukkan pada Gambar 16.

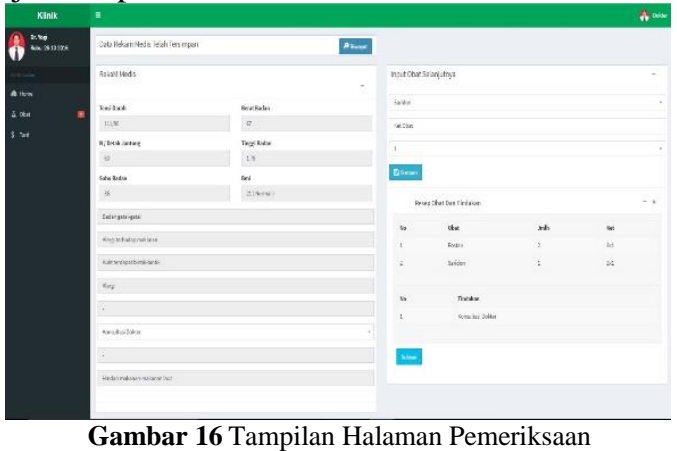

Pada saat akan memeriksa, dokter dapat terlebih dahulu melihat rekam medis pasien dengan menekan tombol riwayat. Berikut ini merupakan tampilan rekam medis pasien ditunjukkan pada Gambar 17.

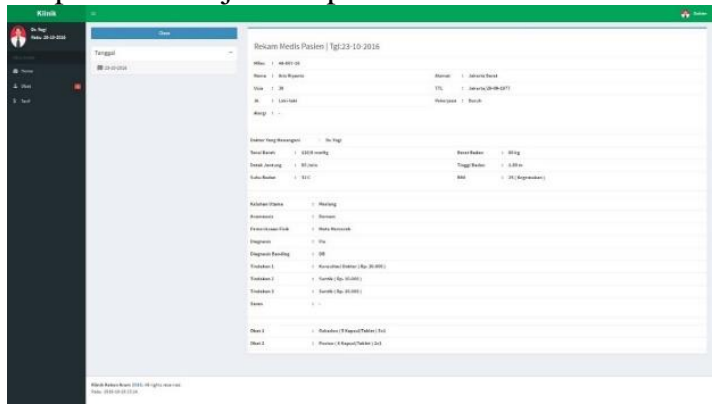

Gambar 17 Tampilan Rekam Medis Pasien 
c. Menu Obat

Menu obat pada dokter digunakan untuk melihat daftar obat beserta harga obat yang tersedia pada klinik.

d. Menu Tarif

Menu tarif pada dokter menunjukkan daftar nama tindakkan beserta tarif tindakan yang dapat dilakukan pada klinik.

\section{Halaman Manajer}

Pada halaman manajer merupakan bagian di mana petugas yang memiliki pangkat atau hak akses sebagai manajer dapat mengelola laporan, data tarif tindakan, dan data obat-obatan.

1. Menu Halaman Utama

Pada menu ini, menandakan bahwa pengguna berhasil login pada menu manajer.

2. Menu Pasien

Pada menu pasien terdapat sub-menu, yaitu menu data dan rekam medis pasien dan menu buku register.

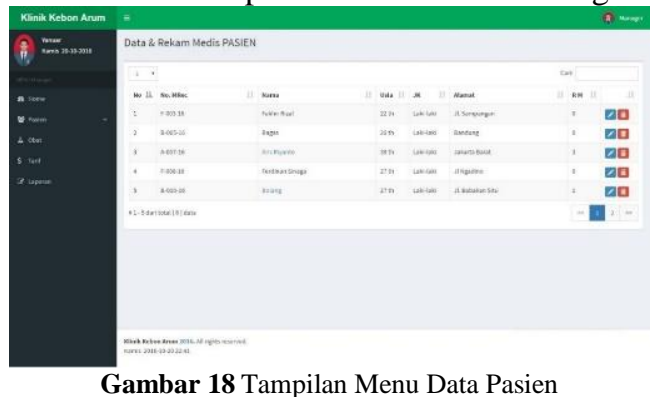

Gambar 18 menujukkan tampilan dari menu data dan rekam medis pasien. Pada setiap pasien memiliki beberapa rekam medis, sehingga saat tombol pada setiap pasien ditekan, akan menampilkan rekam medis pasien tersebut. Gambar 19 merupakan tampilan dari buku register pasien.

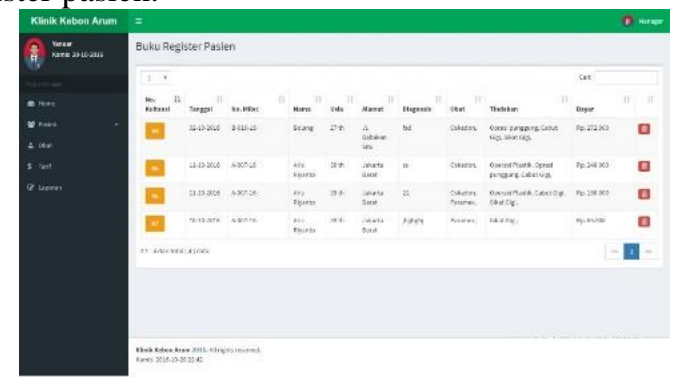

Gambar 19 Tampilan Menu Buku Register Pasien

Terdapat sebuah tombol pada kolom tabel, apabila di tekan akan menampilkan rincian biaya pasien pada saat berkunjung pada tanggal tersebut tersebut, seperti pada Gambar 20.

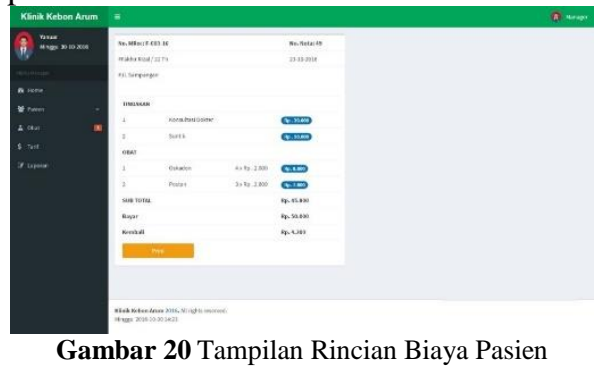

\section{Menu Obat}

Pada menu obat, berisikan data-data lengkap obat-obatan pada klinik. Manajer dapat mengelola obatobatan pada klinik, mulai dari tambah obat baru, edit data obat, tambah stok obat, hingga hapus stok obat.

4. Menu Tarif

Menu Tarif berisikan data tindakan dalam pemeriksaan dan rincian biaya pada klinik. Manajer dapat melakukan tambah tarif baru, edit tarif baru, dan hapus data tarif pada klinik

5. Menu Laporan

Pada menu laporan manajer terdapat beberapa pilihan laporan, antara lain laporan pasien berkunjung, laporan keuangan, laporan penggunaan obat, laporan tindakan pemeriksaan, dan laporan pendapatan dokter. Berikut ini Gambar 21, merupakan tampilan dari menu laporan.

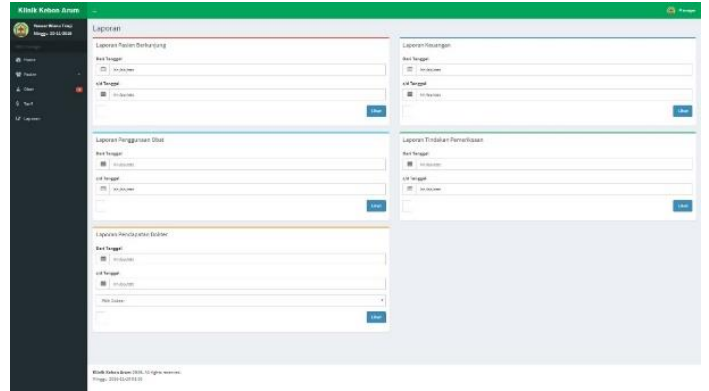

Gambar 21 Tampilan Menu Laporan

Pada tiap laporan terdapat tanggal yang digunakan untuk menentukan periode laporan yang akan di lihat. Berikut ini merupakan tampilan isi dari tiap laporan.
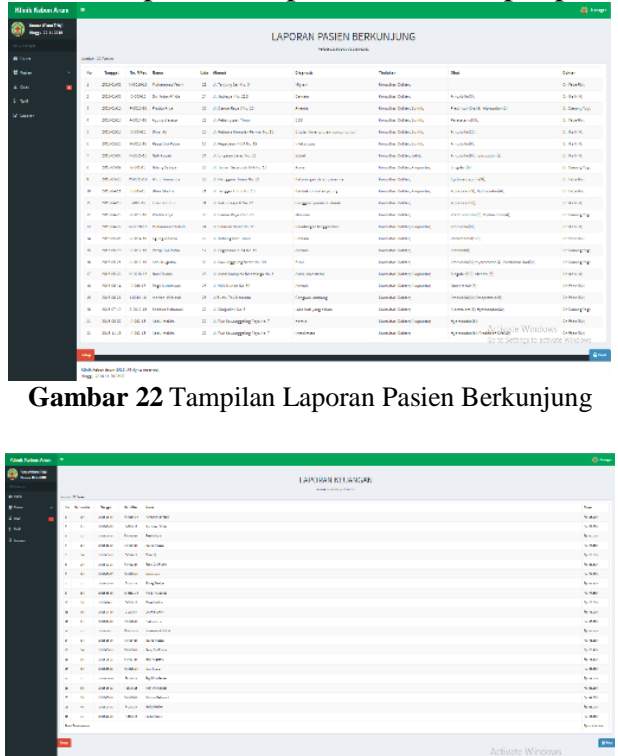

Gambar 23 Tampilan Laporan Keuangan

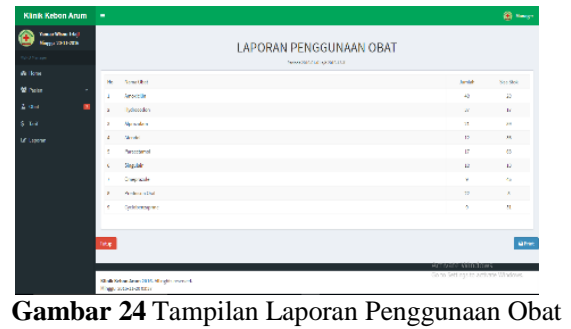




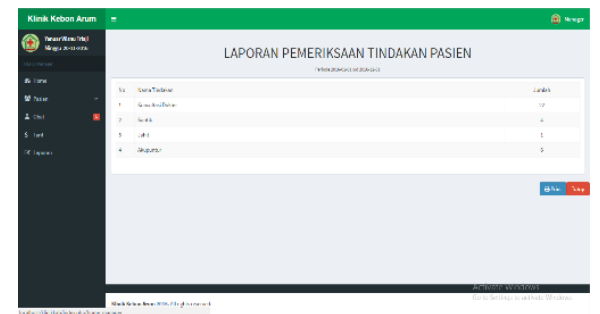

Gambar 25 Tampilan Laporan Pemeriksaan Tindakan

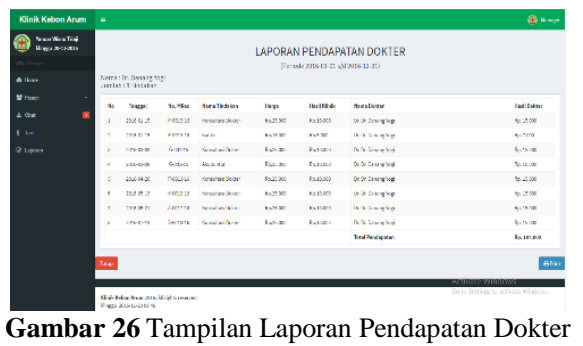

\section{KESIMPULAN}

Berdasarkan pengujian yang dilakukan terhadap aplikasi. Dapat ditarik kesimpulan bahwa sistem berbasis web yang dirancang dengan framework codeigniter mamu menunjukkan kinerja yang maksimal. Basisdata My SQL mampu mengolah data dengan baik sesuai yang diharapkan. Aplikasi berjalan dengan baik dan dapat memenuhi fungsi-fungsi penting dalam manajemen klinik seperti manajemen obat, rekam medis, pemeriksaan, tarif dan lain-lain. Sistem ini siap untuk diimplementasikan di Klinik Kebon Arum Boyolali.

Untuk pengembangan agar alikasi menjadi lebih sempurna, peneliti selanjutnya dapat mengembangkan sistem ini dalam bentuk aplikasi mobile. Selain itu, peneliti selanjutnya juga perlu menambahkan fungsi yang mampu memisahkan pasien regular dengan pasien asuransi dalam penanganan. Dan terakhir, pengembangan fitur laporan keuangan agar memudahkan manajemen keuangan di Klinik Kebon Arum Boyolali.

\section{UCAPAN TERIMA KASIH}

Terimakasih diucapkan kepada klinik Kebon Arum Boyoli atas kesempatan yang telah diberikan sehingga penelitian ini dapat berjalan dengan baik.

\section{DAFTAR Pustaka}

[1] M. Hemmat, Health Information Management, vol. 5, no. 10. Illonois: Physicians Records Company, 2015.

[2] O. U. Effendy, Kamus komunikasi. Bandung: PT. Mandar Maju, 1989.

[3] D. B. Gordon, "Kerangka Dasar Sistem Informasi Manajemen Bagian 1," PT Pustaka Binamas Press. Jakarta, 1991.

[4] R. J. Mcleod, Sistem Informasi Manajemen. Jakarta: PT. Prenhalindo, 1995.

[5] P. Yuliartanto, "Pengembangan Sistem Informasi Rekam Medis Berbasis Web Untuk Dinas Kesehatan Grobogan," 2014.

[6] B. O. Wulandari, "Pembuatan Sistem Informasi Rekam Medis Poliklinik," 2015.

[7] R. V. Imbar and Y. Kurniawan, "Perancangan Sistem Informasi Pelayanan Medis Rawat Jalan Poliklinik Kebidanan dan Kandungan pada RSUD Kota Batam," Sist. Inf., vol. 7, 2012.

[8] M. R. Arief, Pemrograman Web Dinamis Menggunakan PHP dan MySQL. Yogyakarta: ANDI, 2011.

[9] D. D. Prasetyo, Aplikasi Database Client/Server Menggunakan Delphi dan MySQL. Jakarta: PT. Elex Media Komputindo, 2004.

[10] M. S. Rosa A.S, Modul Pembelajaran Rekayasa Perangkat Lunak (Terstruktur dan Berorientasi Obyek), vol. 53, no. 1. Bandung: Modula, 2011. 